\title{
Human adenovirus type identification
}

\author{
Urmila Banik' \\ Arun Kumar Adhikary ${ }^{2}$ \\ 'Unit of Pathology, ${ }^{2}$ Unit of \\ Microbiology, Faculty of Medicine, \\ AIMST University, Bedong, \\ Kedah, Malaysia
}

This article was published in the following Dove Press journal:

Clinical Ophthalmology

15 October 2015

Number of times this article has been viewed

\section{Dear editor}

The published paper in your journal entitling "Human adenovirus type 8 epidemic keratoconjunctivitis with large corneal epithelial full-layer detachment: an endemic outbreak with uncommon manifestations" has come into our attention. ${ }^{1}$ The article provides interesting clinical presentation of corneal epithelial layer detachment among $25 \%$ (4 out of 16 human adenovirus [HAdV]-positive cases) of patients diagnosed with epidemic keratoconjunctivitis (EKC).

However, we have some opinions about the article that are stated below:

First, we have noticed that the authors have used the combination of hexon gene sequence and BLASTN for the typing of HAdV. Due to the appearance of many recombinant types of HAdVs, especially the EKC causing ones, for the last few years, many isolates were wrongly diagnosed as HAdV- 8 by serological method. For example, type HAdV-54 was diagnosed as HAdV-8 due to cross reaction in neutralization test. ${ }^{2}$ Even this was described as genome type HAdV-8I due to its misidentification as HAdV-8. ${ }^{3,4}$ Nowadays, HAdV-54 has become the major agent of EKC in Japan, although a few HAdV-8 is still being isolated in some places. ${ }^{5-9}$ Another EKC causing recombinant type HAdV-53 carries the fiber gene of HAdV-8, penton of HAdV-37, and the hexon of HAdV-22. ${ }^{9}$

Therefore, current recommended type identification method of HAdV is sequencing of the penton $(\mathrm{P})$-hexon $(\mathrm{H})$-fiber $(\mathrm{F})$ genes (molecular typing) or whole genome sequence. ${ }^{10}$

Second, the authors used the term HAdV-8 genotype on the basis of HAdV-8 hexon sequence followed by BLASTN. Now a days, PCR amplification and sequencing of variable regions within the hexon, penton base, and fiber genes is designated as molecular typing method.

The term genotype is used for the recognition of a new type by full genome sequence. A genotype number is assigned where sequence data reveal that either i) the virus isolate encodes novel hexon (loops 1 and 2), penton base (hypervariable region), and fiber (knob) sequences, or ii) is a recombinant with one or two of these regions derived from previously designated genotypes, or iii) is a recombinant that has a unique combination of these three regions derived from previously recognized genotypes. ${ }^{10}$

Third, in the discussion, the authors described HAdV-8C-H genome types as genotypes. Traditionally, genome types of HAdV are designated by the restriction endonuclease cleavage pattern analysis of viral DNA. ${ }^{11}$

We hope the authors will perform the currently recommended methods to confirm the identity of their EKC causing HAdVs.
Correspondence: Urmila Banik Unit of Pathology, Faculty of Medicine, AIMST University, Bedong 08I00, Kedah, Malaysia

Email urmila_banik@yahoo.co.in 


\section{Disclosure}

The authors report no conflicts of interest in this work.

\section{References}

1. Lee YC, Chen N, Huang IT, et al. Human adenovirus type 8 epidemic keratoconjunctivitis with large corneal epithelial full-layer detachment: an endemic outbreak with uncommon manifestations. Clin Ophthalmol. 2015;9:953-957.

2. Kaneko H, Suzutani T, Aoki K, et al. Epidemiological and virological features of epidemic keratoconjunctivitis due to new human adenovirus type 54 in Japan. Br J Ophthalmol. 2011;95(1):32-36. doi:10.1136/bjo. 2009.178772.

3. Adhikary AK, Numaga J, Kaburaki T, et al. Genetic characterisation of adenovirus type 8 isolated in Hiroshima city over a 15 year period. $J$ Clin Pathol. 2003;56(2):120-125.

4. Adhikary AK, Ushijima H, Fujimoto T. Human adenovirus type 8 genome typing. J Med Microbiol. 2012;61(Pt 11):1491-1503. doi:10.1099/jmm. 0.044172-10.

5. Ishiko H, Shimada Y, Konno T, et al. Novel human adenovirus causing nosocomial epidemic keratoconjunctivitis. J Clin Microbiol. 2008;46(6): 2002-2008. doi:10.1128/JCM.01835-07.
6. Ishiko H, Aoki K. Spread of epidemic keratoconjunctivitis due to a novel serotype of human adenovirus in Japan. J Clin Microbiol. 2009;47(8): 2678-2679. doi:10.1128/JCM.r00313-109.

7. Akiyoshi K, Suga T, Fukui K, Taniguchi K, Okabe N, Fujimoto T. Outbreak of epidemic keratoconjunctivitis caused by adenovirus type 54 in a nursery school in Kobe City, Japan in 2008. Jpn J Infect Dis. 2011; 64(4):353-355.

8. Fujimoto T, Matsushima Y, Shimizu H, et al. A molecular epidemiologic study of human adenovirus type 8 isolates causing epidemic keratoconjunctivitis in Kawasaki City, Japan in 2011. Jpn J Infect Dis. 2012; 65(3):260-263.

9. Nakamura M, Hirano E, Kowada K, et al. Surveillance of adenovirus D in patients with epidemic keratoconjunctivitis from Fukui Prefecture, Japan, 1995-2010. J Med Virol. 2012;84(1):81-86. doi:10.1002/jmv. 22252.

10. Seto D, Chodosh J, Brister JR, Jones MS; Members of the Adenovirus Research Community. Using the whole-genome sequence to characterize and name human adenoviruses. $J$ Virol. 2011;85(11):5701-5702. doi: 10.1128/JVI.00354-11.

11. Adrian T, Wadell G, Hierholzer JC, Wigand R. DNA restriction analysis of adenovirus prototypes 1 to 41. Arch Virol. 1986;91(3-4):277-290.

Dove Medical Press encourages responsible, free and frank academic debate. The content of the Clinical Ophthalmology 'letters to the editor' section does not necessarily represent the views of Dove Medical Press, its officers, agents, employees, related entities or the Clinical Ophthalmology editors. While all reasonable steps have been taken to confirm the content of each letter, Dove Medical Press accepts no liability in respect of the content of any letter, nor is it responsible for the content and accuracy of any letter to the editor.

Clinical Ophthalmology

\section{Publish your work in this journal}

Clinical Ophthalmology is an international, peer-reviewed journal covering all subspecialties within ophthalmology. Key topics include: Optometry; Visual science; Pharmacology and drug therapy in eye diseases; Basic Sciences; Primary and Secondary eye care; Patient Safety and Quality of Care Improvements. This journal is indexed on Submit your manuscript here: http://www.dovepress.com/clinical-ophthalmology-journal

\section{Dovepress}

PubMed Central and CAS, and is the official journal of The Society of Clinical Ophthalmology (SCO). The manuscript management system is completely online and includes a very quick and fair peer-review system, which is all easy to use. Visit http://www.dovepress.com/ testimonials.php to read real quotes from published authors. 